\title{
PENERAPAN MEDIA PEMBELAJARAN MODUL ELEKTRONIK UNTUK MENINGKATKAN HASIL BELAJAR SISWA PADA MATA PELAJARAN TEKNOLOGI MEKANIK
}

\author{
Nandya R. J. Hafsah ${ }^{1}$, Dedi Rohendi ${ }^{2}$, Purnawan ${ }^{3}$ \\ Departemen Pendidikan Teknik Mesin \\ Universitas Pendidikan Indonesia \\ Jl. Dr. Setiabudhi No. 207 Bandung 40154 \\ nandyaritsi_pp@rocketmail.com
}

\begin{abstract}
ABSTRAK
Penelitian ini bertujuan untuk mengetahui peningkatan hasil belajar siswa yang menggunakan $e$ modul dan modul cetak serta mengetahui terdapat atau tidaknya perbedaan peningkatan hasil belajar siswa antara kelompok yang menggunakan e-modul dengan kelompok yang menggunakan modul cetak. Metode yang digunakan pada penelitian ini adalah metode quasi eksperiment dengan desain penelitian nonequivalent control group design. Pada penelitian ini dilakukan pre-test dan post-test untuk mengetahui peningkatan hasil belajar siswa. Peningkatan hasil belajar siswa tersebut dinyatakan dengan $\mathrm{N}$-Gain. Hasil penelitian menunjukkan bahwa kedua media pembelajaran yang digunakan dapat meningkatkan hasil belajar siswa, dimana nilai rata-rata $N$-Gain untuk kedua kelompok memiliki kriteria sedang. Tidak terdapat perbedaan peningkatan hasil belajar siswa antara kelompok yang menggunakan $e$-modul dengan kelompok yang menggunakan modul cetak.
\end{abstract}

Kata kunci: pneumatik, e-modul, modul cetak, hasil belajar, teknologi mekanik.

\section{PENDAHULUAN}

Pada tahun 2013 memberikan perubahan besar pada dunia pendidikan dengan mengubah Kurikulum Tingkat Satuan Pendidikan (KTSP) menjadi Kurikulum 2013. Kurikulum 2013 merupakan pengembangan dari kurikulum berbasis kompetensi. Pada kurikulum 2013 terdapat mata pelajaran baru yang sebelumnya belum pernah ada khususnya untuk SMK jurusan teknik mesin dengan paket keahlian teknik pemesinan, salah satunya yaitu mata pelajaran teknologi mekanik. Mata pelajaran teknologi mekanik salah satunya membahas tentang materi pneumatik. Materi pneumatik bertujuan agar siswa dapat mengetahui komponen dan cara kerja dari suatu mesin dan sistem kontrol. Materi pneumatik membahas tentang fungsi sistem pneumatik, cara kerja sistem pneumatik, bagian-bagian sistem pneumatik dan aplikasi sistem pneumatik. Pada sub materi bagian-bagian sistem pneumatik tersebut salah satunya membahas tentang katup pneumatik.

\footnotetext{
${ }^{1}$ Mahasiswa Departemen Pendidikan Teknik Mesin FPTK UPI

${ }^{2}$ Dosen Departemen Pendidikan Teknik Mesin FPTK UPI

${ }^{3}$ Dosen Departemen Pendidikan Teknik Mesin FPTK UPI
} 
Pembelajaran katup pneumatik, terdapat materi mengenai simbol-simbol dan cara kerja katup pneumatik. Pada materi simbol-simbol dan cara kerja katup pneumatik terdapat simbol katup-katup yang terstandar sehingga siswa akan sulit untuk memahaminya. Apabila simbol-simbol katup pneumatik tersebut menggunakan media yang bersifat abstrak maka siswa akan kesulitan untuk memahaminya karena dibutuhkan pemikiran dan imajinasi yang kuat untuk memahami cara kerja katup pneumatik. Maka dalam menjelaskan simbol dan cara kerja katup pneumatik dibutuhkan media yang lebih mendakati keadaan nyatanya sehingga siswa akan mudah untuk memahaminya. Hal tersebut seiringan dengan pendapat mengenai hubungan media pembelajaran terhadap pengalaman belajar teori kerucut pengalaman Edgar Dale.

Media berbentuk teks mempunyai degree of abstraction yang tinggi karena peserta didik harus memahami dan mengerti tentang materi yang diberikan dalam bentuk teks tersebut. Degree of abstraction semakin menurun dengan peningkatan pengalaman yang diterima peserta didik, misalnya kalau media pembelajaran hanya berbentuk teks tidak mampu memberikan pengalaman yang lebih dari panca indera selain mata, tetapi dengan media yang lebih kompleks misalnya simulasi memberikan pengalaman yang lebih banyak karena banyak anggota tubuh yang terlibat, mulai dari mata, telinga, dan seterusnya (Chomsin, dan Jasmadi, 2008). Pengalaman belajar dan media pembelajaran yang semakin banyak anggota tubuh yang terlibat dalam proses pembelajaran, maka tingkat kompetensi yang didapatkan oleh peserta didik juga semakin banyak, antara lain kognitif, keterampilan, dan sikap.

Salah satu media pembelajaran yang mendekati keadaan nyatanya yaitu modul elektronik. Modul elektronik merupakan salah satu media berbantuan komputer yang didalamnya terdapat gambar animasi dari simbol dan cara kerja katup pneumatik. Gambar animasi atau gambar bergerak katup pneumatik tersebut mendekati keadaan nyatanya sehingga memudahkan siswa untuk memahami simbol dan cara kerja katup pneumatik. Modul elektronik merupakan media pembelajaran berbasis komputer. Komputer dapat mengakomodasi siswa yang lamban menerima pelajaran, karena dapat memberikan iklim yang lebih bersifat afektif dengan cara yang lebih individual, tidak pernah lupa, tidak pernah bosan, sangat sabar dalam menjalankan instruksi seperti yang diinginkan program yang digunakan (Arsyad, 2013). Salah satu kelemahan dari media pembelajaran berbasis komputer bahwa komputer hanya efektif bila digunakan oleh satu orang atau beberapa orang dalam kelompok kecil. Untuk kelompok yang besar 
diperlukan tambahan peralatan lain yang mampu memproyeksikan pesan-pesan di monitor ke layar lebih lebar. Oleh karena itu, penerapan modul elektronik pada proses pembelajaran untuk meningkatkan hasil belajar siswa menjadi hal yang perlu dibuktikan.

Selain menggunakan modul elektronik, modul cetak pun digunakan sebagai pembanding peningkatan hasil belajar siswa. Modul cetak merupakan media pembelajaran berbasis cetakan atau media pembelajaran berupa print-out. Keunggulan media berbasis cetakan bahwa materi pembelajaran dapat dirancang sedemikian rupa sehingga mampu memenuhi kebutuhan siswa, baik yang cepat maupun yang lamban membaca dan memahami. Namun, pada akhirnya semua siswa diharapkan dapat menguasai materi pengajaran itu. Modul cetak memiliki keunggulan lebih praktis dan murah. Oleh karena itu, modul cetak sangat cocok digunakan sebagai pembanding media pembelajaran yang diterapkan pada proses pembelajaran khususnya pada materi katup pneumatik.

Tujuan penelitian ini untuk mengetahui gambaran peningkatan hasil belajar siswa pada siswa yang menggunakan modul elektronik, mengetahui gambaran peningkatan hasil belajar siswa pada siswa yang menggunakan modul cetak, dan mengetahui perbedaan peningkatan hasil belajar siswa antara yang menggunakan modul elektronik (E-modul) dengan yang menggunakan modul cetak.

Hasil belajar merupakan kemampuan yang dimiliki siswa setelah ia menerima pengalaman belajarnya (Sudjana, 2011). Gambaran dari potensi diri yang dimiliki setelah proses pembelajaran dapat dilihat dari hasil belajar siswa tersebut. Peningkatan hasil belajar siswa dapat dilihat dari nilai $N$-Gain yang diperoleh siswa tersebut. Uji $N$ Gain dipergunakan untuk mengukur peningkatan penguasaan konsep siswa.

\section{METODE PENELITIAN}

Metode penelitian yang digunakan adalah Metode Quasi Eksperiment. Pada metode quasi eksperimen. Rancangan eksperimen ini tidak dapat sepenuhnya melakukan pengendalian terutama dalam penentuan kelompok melalui random assignment. Rancangan ini terdiri dari dua kelompok yaknik kelompok eksperimen dan kelompok kontrol, kelompok eksperimen dan kontrol dikenakan pre-test terlebih dahulu kemudian kelompok eksperimen diberi perlakuan tertentu. Untuk kemudian baik 
kelompok control maupun kelompok eksperimen dikanakan post-test untuk melihat efek dari perlakuan pada kelompok eksperimen.

Populasi pada penelitian ini adalah seluruh siswa paket keahlian teknik pemesinan SMK Negeri 1 Katapang Kabupaten Bandung yang sebanyak 247 siswa. Sampel pada penelitian ini adalah seluruh siswa yang mengikuti mata pelajaran teknologi mekanik pada semester ganjil tahun ajaran 2014/2015 yang terdiri dari 60 siswa yang terbagi pada dua kelompok yaitu kelas X MP 1 yang berjumlah 27 siswa yang merupakan kelompok eksperimen pertama dan kelas X MP 2 yang berjumlah 33 siswa yang merupakan kelompok eksperimen kedua. Untuk teknik pengambilan sampel, penelitian ini menggunakan sampel purposif (purposive sampling) karena kelas yang tersedia di SMKN 1 Katapang hanya terdapat dua kelas yang sedang mempelajari pneumatik, jadi tidak memungkinkan untuk menggunakan sampel random.

\section{HASIL PENELITIAN}

Skala penilaian hasil belajar pada penelitian ini menggunakan skala 0-4, agar sesuai dengan implementasi Kurikulum 2013. Data pre-test, post-test dan $\mathrm{N}$-Gain dapat dijelaskan pada Tabel 1.

Tabel 1. Hasil pre-test, post-test dan N-Gain

\begin{tabular}{|c|c|c|c|c|c|c|c|c|c|c|c|c|}
\hline \multirow{2}{*}{ Kelompok } & \multicolumn{4}{|c|}{ Skor Pre-test } & \multicolumn{4}{|c|}{ Skor Post-test } & \multicolumn{4}{|c|}{$N$-Gain } \\
\hline & $\min$ & Max & $\bar{x}$ & $\mathrm{Sd}$ & $\min$ & $\max$ & $\bar{x}$ & $\mathrm{Sd}$ & $\min$ & $\max$ & $\bar{x}$ & $\mathrm{Sd}$ \\
\hline $\begin{array}{l}\text { EKsper1- } \\
\text { men } 1\end{array}$ & 0,4 & 1,3 & 0,8 & 0,2 & $1,($ & 3,6 & 2,1 & 0 & 0,17 & 0,88 & 0,40 & 14 \\
\hline $\begin{array}{c}\text { Eksperi- } \\
\text { men } 2\end{array}$ & 0,4 & 1,2 & 0,8 & 0,24 & 0,9 & 3,1 & 2,0 & 0,5 & 0,03 & 0,68 & 0,38 & 0,15 \\
\hline
\end{tabular}

Pada kelompok eksperimen pertama yaitu kelompok yang menggunakan modul elektronik terdapat nilai hasil pre-test dan post-test setelah dilakukannya penelitian. Nilai antara nilai pre-test dan post-test pada kelompok eksperimen 1 diperoleh nilai, sebagai berikut: $\mathrm{B}+=7,4 \%, \mathrm{C}+=7,4 \%, \mathrm{C}=50,7 \%, \mathrm{C}-=29,6 \%$, dan $\mathrm{D}+=2.1 \%$. Selain itu, pada penelitian ini media pembelajaran lain yang digunakan sebagai pembanding yaitu modul cetak. Kelompok yang menggunakan modul cetak ini adalah kelompok eksperimen 2. Setelah dilakukan penelitian, pada kelompok ekperimen 2 terdapat nilai pre-test dan post-test. Nilai antara nilai pre-test dan post-test pada kelompok eksperimen 1 diperoleh nilai, sebagai berikut: $\mathrm{B}=3 \%, \mathrm{~B}-=15,2 \%, \mathrm{C}+=9,1 \%, \mathrm{C}=24,2 \%$, $\mathrm{C}-=30,3 \%$, dan $\mathrm{D}+=15,2 \%$, dan $\mathrm{D}=3 \%$. 


\section{PEMBAHASAN}

Pada kelompok eksperimen 1 yang merupakan kelompok yang menggunakan modul elektronik terdapat nilai hasil pre-test dan post-test setelah dilakukannya penelitian. Hasil pre-test pada kelompok eksperimen 1 menghasilkan nilai rata-rata D. Hasil tersebut, menyatakan bahwa kelompok tersebut belum mendapatkan atau mempelajari materi katup pneumatik terutama materi mengenai simbol dan cara kerja katup pneumatik sebelumnya pada mata pelajaran teknologi mekanik. Setelah diberikan treatment dengan menggunakan modul elektronik, didapat nilai post-test kelompok eksperimen 1. Rata-rata nilai post-test untuk kelompok eksperimen 1 adalah C.

Pada ketuntasan hasil belajar siswa pada kelompok siswa yang menggunakan modul elektronik yang memenuhi nilai KKM pada materi simbol dan cara kerja katup pneumatik sebanyak 3 siswa atau persentase sekitar 11,1\%. Apabila kita melihat dan membandingkan nilai hasil pre-test dan post-test, dapat dikatakan modul elektronik tersebut dapat meningkatkan hasil belajar siswa khususnya untuk materi katup pneumatic (Kustiandi, dan Bambang, 2011). Setelah didapat nilai pre-test dan post-test, kita dapat mengetahui peningkatan hasil belajar siswa yaitu dengan menghitung nilai $\mathrm{N}$ Gain. Rata-rata peningkatan hasil belajar siswa atau N-Gain pada kelompok eksperimen 1 sebesar 0.40, sehingga dapat dikatakan peningkatan hasil belajar siswa dengan menggunakan modul elektronik memiliki kategori sedang.

Sebagai pembanding, digunakan modul cetak dalam proses pembelajaran untuk kelompok eksperimen 2. Sebelum dilakukannya treatment, maka kita harus mengambil data awal untuk melihat kondisi awal atau pre-test kelompok eksperimen 2. Rata-rata hasil nilai pre-test pada kelompok yang menggunakan modul cetak adalah D. Hasil pretest yang telah didapat, menyatakan bahwa kelompok tersebut belum mendapatkan atau mempelajari materi katup pneumatik terutama materi mengenai simbol dan cara kerja katup pneumatik sebelumnya. Setelah dilakukannya treatment, maka didapat nilai posttest dengan rata-rata nilai untuk kelompok yang menggunakan modul cetak memiliki kriteria C. Apabila dilihat dari ketuntasan hasil belajara siswa pada kelompok siswa yang menggunakan modul elektronik yang memenuhi nilai KKM pada materi simbol dan cara kerja katup pneumatik sebanyak 6 siswa atau persentase sekitar 18,2\%. Untuk melihat besar peningkatan hasil belajar siswa maka dilakukanlah perhitungan $\mathrm{N}$-Gain . Pada kelompok yang menggunakan modul cetak memiliki rata-rata peningkatan hasil belajar siswa dengan kategori sedang. 
Dengan membandingkan nilai pre-test, post-test, dan $N$-gain, penerapan kedua media tersebut memiliki kesamaan dan perbedaan. Apabila melihat kesamaanya diantaranya yaitu kondisi awal kedua kelompok yang belum mempelajari materi katup pneumatic. Kedua modul tersebut dapat meningkatkan hasil belajar siswa, dan memiliki rata-rata nilai $N$-Gain dan post-test yang sama dengan kriteria sedang. Namun apabila dilihat perbedaannya diantaranya yaitu nilai tertinggi kelompok eksperimen 1 lebih besar daripada kelompok eksperimen 2. Ketuntasan hasil belajar siswa kelompok yang menggunakan modul cetak lebih banyak daripada kelompok yang menggunakan modul elektronik.

Hasil uji homogenitas yaitu kedua kelompok baik kelompok yang menggunakan modul elektronik maupun modul cetak dinyatakan homogen. Sedangkan hasil dari pengujian normalitas yaitu kedua kelompok eksperimen tersebut dikatakan berdistribusi normal. Untuk mengetahui perbedaan peningkatan hasil belajar siswa, dilakukanlah pengujian hipotesis. Adapun hasil pengujian hipotesis yang telah didapat pada penelitian ini bahwa Ho diterima. Ho diterima, artinya tidak terdapat perbedaan peningkatan hasil belajar siswa dalam pembelajaran materi katup pneumatik pada mata pelajaran teknologi mekanik antara yang menggunakan modul elektronik dengan yang menggunakan modul cetak di SMK Negeri 1 Katapang.

Hasil penelitian pada penelitian ini sangat berbeda dengan teori kerucut pengalaman belajar Edgar Dale. Berdasarkan teori kerucut pengelaman Edgar Dale, seharusnya terdapat perbedaan peningkatan hasil belajar siswa antara kelompok yang menggunakan modul elektronik dengan kelompok yang menggunakan modul cetak. Menurut kerucut Edgar Dale, gambar animasi atau gambar yang bergerak akan memberikan pengalaman belajar yang lebih besar dari pada gambar yang diam atau media cetak, sehingga akan terdapat perbedaannya, namun kenyataannya pada penelitian ini menghasilkan kedua media pembelajaran tidak terdapat perbedaan.

Kedua media pembelajaran tidak terdapat perbedaan pada mata pelajaran teknologi mekanik diakibatkan oleh beberapa faktor. Faktor utama yang mempengaruhi adalah kekurangan modul elektronik lebih menonjol pada proses pembelajaran berlangsung dibandingkan kelebihannya dan kelebihan dari modul cetak lebih menonjol daripada kekurangannya pada proses pembelajaran khususnya pada materi katup pneumatic (Sungkono, 2009).. Faktor lainnya yang mempengaruhi diantaranya yaitu siswa, pendidik, metode pembelajarannya, dan lainnya. 


\section{KESIMPULAN}

Kesimpulan dari penelitian ini, sebagai berikut peningkatan hasil belajar siswa yang menggunakan media pembelajaran modul elektronik memiliki kriteria sedang. Peningkatan hasil belajar siswa yang menggunakan media pembelajaran modul cetak memiliki kriteria sedang. Perbedaan peningkatan hasil belajar siswa dalam pembelajaran materi katup pneumatik pada mata pelajaran teknologi mekanik antara yang menggunakan modul elektronik dengan yang menggunakan modul cetak di SMK Negeri 1 Katapang.

\section{DAFTAR PUSTAKA}

Arsyad, A. (2013). Media pembelajaran. Jakarta: PT. Raja Grafindo Persada.

Chomsin, W.S. dan Jasmadi. (2008). Panduan menyusun bahan ajar berbasis kompetensi. Jakarta: PT. Elex Media Komputindo.

Kustiandi, C. dan Bambang, S. (2011). Media Pembelajaran Manual dan Digital. Bogor: Ghalia Indonesia.

Sudjana, N. (2011). Penilaian hasil proses belajar mengajar. Bandung: PT Remaja Rosdakarya.

Sungkono. (2009). Pengembangan Bahan Ajar. Yogyakarta: Universitas Negeri Yogyakarta 